\title{
Animation Film in Writing Teaching Instruction on Narrative Text: Working or not Working?
}

\author{
Salasiah Ammade \\ Universitas Muhammadiyah Parepare \\ salasiah@umpar.ac.id \\ Ika Yanti Ziska \\ Universitas Muhammadiyah Parepare \\ ikayantiziska@gmail.com
}

\begin{abstract}
The teaching writing is still in need of interesting teaching media to support its pedagogy as teaching writing is associated with difficult subject to be taught. Prior researches have been conducted on teaching writing area and the result suggested conducting more study on teaching writing effectively. This study attempts to fulfill the gap and takes teaching media as the focus of the research. This article investigated the employment of animated films as a teaching medium in the teaching of narrative writing tests, as well as if they are still effective in supporting the learning process. The sample of the research was taken from the students of a Junior high school in Parepare, Indonesia which was chosen purposively. Online Google Forms was employed as research tools for the study, and the questionnaire and test writing were used to collect data. Quantitative analysis was used in analyzing the data gathered. Regarding the research result, the data revealed that there is difference result between before and after the research. Students respond positively to an animation video utilized in the study as an alternate media in teaching narrative text of writing. They enjoyed the learning process of writing narrative text via animation film as the media as well as improved their positive energy in writing. It can be suggested for the next researcher to study more in another issue of animation film for teaching.
\end{abstract}

Keywords: Animation film, teaching writing, narrative text, teaching media

\section{INTRODUCTION}

A numbers of teaching media have been explored in assisted teaching learning process including media assistance in teaching writing of English. It is general knowledge in language teaching that writing, along with listening, speaking, and reading, is recommended to be taught as much as possible. Tarigan (2008), conveyed the importance of writing as a language skill used to communicate with others directly or indirectly. Additionally, writing is part of a productive and expressive activity as well as it is a way to take out ideas in the mind to be put in written form (Hyland, 2002).

The act or process of writing consists of finding and structuring ideas, putting them on paper, and then revising and editing them. In written form, students are free to share whatever they wish.
Writing, according to Hyland (2002), can help kids get their thoughts out of their heads and into different formats so that others can read and consider them. This means that everyone can write down their thoughts and connect with others.

Consider the importance of learning to write in English, it can expand and improve the growth of student vocabulary; improve the fluency of writing and composing student sentences. Writing activities can improve students' ability to organize, encourage prospective writers or students who are used to develop personal writing styles and are accustomed to finding organizations that fit their own ideas. Terry and Hughes (2010) argued that writing is important because it allows us to convey ideas from our heads. It is not easy to transform a mental thought into written language, and we must be 
astute in selecting and combining vocabulary to make something significant. Additionally, students must also be mindful of grammar, and this is why they think writing is a difficult topic because they must take into consideration so many different elements (grammar, vocabulary, concept and idea). Apart from that, another point that makes writing the most difficult subject is the variety of texts in English, such as narrative, descriptive, recount, mock, and so on. Each text has its own unique characteristics, such as general structure, social function, and grammatical characteristics. These factors make it difficult for children to discern between texts, and they may mix different types of texts. It will be a problem for the teacher to figure out how the kids can differentiate between different types of texts.

Teachers struggle to get pupils to develop ideas and turn them into sentences in English writing classes. Therefore, the important thing to be prepared by the teacher before teaching is how to teach writing English in fun way, not boring and can make students excited and interested in learning to write narrative text. In this study, researchers suggest teachers to teach and improve students' writing abilities using one of the media such as film animation because by using film animation will display more interesting images along with sounds that make students better understand the topic of the text.

Considering the writers' observation in one of junior schools in Parepare, South Sulawesi province, Indonesia. It can be seen the average student is less able to write well due to several factors such as learning media, learning models and the way teachers teach at school. This is evidenced by seeing the low ability to write when students were given the task to write with the topic "an unforgettable moment in his life". Other problem appears deal with the lack presentation of teaching media in class.

Regarding the problem above, the research is going focus on offering solutions to help overcome these problems by providing more interesting learning media for students, especially in writing stories in the form of narrative texts, namely by using film animation media. Teaching students to write with film animation is predictable to be effective and can make students more interested in writing.

Previous studies on film in teaching writing have been done by some researchers like Wahyuni, 2017; Agnes, 2017; Siswanjaya, 2017; Dyah, 2013; Tatum, 2011; Abdia, 2016. The researchers discovered that students who were given an animation film to help them learn to write narrative text were better able to produce narrative text and dealt with the structure of the text properly. The implementation of animation films in these studies showed positive responses from students as they can write narrative texts easier. According to the teacher, employing animation films makes it harder for students to grasp the purpose of actual English spoken by native speakers. As a result, the researchers came to the conclusion that using animation films to teach students how to write narrative texts is a good idea. By watching animation films as a medium in teaching narrative writing, students' motivation and enthusiasm get high in teaching write narrative texts.

The preceding studies have a lot in common with this one since it uses animation films as a learning medium to help students improve their narrative writing skills. Nevertheless, there are some differences in my research with the research among them. The first difference is on research subject. Subjects on above research were in senior high school while my research subject will be at junior high school. Besides the subject and location, the second difference is the material or film to be shown, although both use animation films but the film will be shown to students or different subjects.

\section{METHODOLOGY}

The study used a one-group pre-test post-test design with a pre-experimental approach. The participants in this study were the ninth-year students at SMP Negeri 6 Parepare in the academic year 2020/2021, who were divided into three classes, each with 21 individuals. There are 63 students in the overall population.

Due to the large population, the sampling approach employed in this study was cluster random sampling. The sample consisted of 21 students from class IX.3. The writing exam and an 
online questioner via Google form were employed as research instruments in this study. This was used in both the pre-test and post-test. The pre-test was used to assess students' writing abilities prior to therapy, and the post-test was used to assess students' progress in producing narrative prose.

The researcher treats the students in the treatment by using animated videos to teach narrative text.. Due to pandemic COVID 19 situation, online learning was the way to teach by using social media (Whatsaap Groups). The researcher conducted research during four meetings.

\section{RESULT AND DISCUSSION}

There are several findings that will be described in this discussion. First, animation films as a medium in the learning process can assist students' in making narrative text. Second finding was the animation films can be an alternative media used by teachers during the learning process so the learning process may be more varied. To determine the positive change in students' writing skills of narrative text using animation film, the researcher applied all procedures as stated in the method.

\section{The students' writing ability}

The students' writing ability in the study was reported within two phases, before the research and post research. The writing ability was tested out using writing test and the result of it will be described further. On the pretest result of ninth grade students of UPTD SMPN 6 Parepare was clearly tabulated at below table.

Table 1: The frequency and percentage of the students' score in pre-test

Table 1: The frequency and percentage of pretest

\begin{tabular}{lllll}
\hline \multirow{2}{*}{ No } & Classification & $\begin{array}{l}\text { Score } \\
\text { Interval }\end{array}$ & \multicolumn{2}{l}{ Pre-Test } \\
\cline { 3 - 5 } & & F & $\%$ \\
\hline 1 & Very good & $88-100$ & & \\
\hline 2 & Good & $73-87$ & 2 & 9.52 \\
\hline 3 & Fair & $58-72$ & 16 & 76.19 \\
\hline 4 & Poor & $43-57$ & 3 & 14.28 \\
\hline 5 & Very poor & $<42$ & & \\
\hline & Total & & 21 & 100 \\
\hline
\end{tabular}

The table indicates students' writing was varied. In good classification, two students $(9,52 \%)$ got interval score $73-87$ of twentyone students, there were sixteen $(76,19 \%)$ of them in fair classification, and then three students (14, 28\%) were in poor classification. It can be concluded here that students' writing ability before giving learning with animation film assistance was still quite low.

The result of post-test of ninth grade students of UPTD SMPN 6 Parepare after being given treatment can be presented at the following table.

Table 2: The frequency and percentage of the students' score in post-test

Table 2: The frequency and percentage of posttest

\begin{tabular}{ccccc}
\hline \multirow{2}{*}{ No } & Classification & Score & \multicolumn{2}{c}{ Post-test } \\
\cline { 3 - 5 } & & Interval & F & $\%$ \\
\hline 1 & Very good & $88-100$ & 3 & 14.28 \\
\hline 2 & Good & $73-87$ & 15 & 71.42 \\
\hline 3 & Fair & $58-72$ & 3 & 14.28 \\
\hline 4 & Poor & $43-57$ & & \\
\hline 5 & Very poor & $<42$ \\
\hline \multicolumn{5}{r}{ Total } \\
\hline
\end{tabular}

The classification of the score of post-test above indicates that after teaching writing through animation films, most of the students got a good score. There were three students $(14,28 \%)$ in very good classifications, fifteen students $(71,42 \%)$ students were categorized as good and then three students $(14,28 \%)$ were in fair level. The result of the data shown above implies the implementation of animation films can assist students in writing narrative text.

In showing the mean score and standard deviation of pre-test and post-test, the table below will be covered the data.

Table 3: The mean score, standard deviation and giant score of the students

Table 3: The mean score, standard deviation and giant score of the students 


\begin{tabular}{|c|c|c|c|c|}
\hline No & Classification & Score & Frequency & $\begin{array}{l}\text { Percentage } \\
(\%)\end{array}$ \\
\hline 1 & Really Agree & $80-100$ & 6 & 28.57 \\
\hline 2 & Agree & $65-80$ & 15 & 71.42 \\
\hline 3 & Enough & $55-65$ & & \\
\hline 4 & Less Agree & $40-55$ & & \\
\hline $\begin{array}{ll}5 & N \\
\end{array}$ & Not Agree & $0-40$ & & \\
\hline \multicolumn{2}{|c|}{ TOTAL } & & 21 & $100 \%$ \\
\hline \multicolumn{2}{|c|}{ Mean Score } & & 77.61 & (Highest) \\
\hline No & $\begin{array}{ll}\text { o } & \text { Type of } \\
\text { Test }\end{array}$ & $\begin{array}{l}\text { Mean } \\
\text { Score }\end{array}$ & $\begin{array}{l}\text { Standard } \\
\text { Deviation }\end{array}$ & $\begin{array}{l}\text { Giant } \\
\text { Score }\end{array}$ \\
\hline 1 & Pre-test & 64.85 & 6.59 & 14.19 \\
\hline 2 & Post-test & 79.04 & 6.48 & \\
\hline
\end{tabular}

animation films was to help improve students' writing skills can be seen in table 5 .

Table 4: The result of $t$-test and $t$-table value

\begin{tabular}{llll}
\hline No & Variable & $\begin{array}{c}\text { t-test } \\
\text { value }\end{array}$ & $\begin{array}{l}\text { t-table } \\
\text { value }\end{array}$ \\
\hline 1 & $\mathrm{X}_{1}-\mathrm{X}_{2}$ & 14.62 & 1.725
\end{tabular}

The table above displays that most of the ninth grade students at UPTD SMP Negeri 6 Parepare agreed that film animation can be an alternative media in assisting students' in writing narrative text. It is clearly seen at the table, out of 21 students, 6 $(28.57 \%)$ of them answered really agree, and 15 $(71.42 \%)$ students answered agree. The final result of the analysis shows that the average value obtained was 77.61 which were categorized as the highest value.

As presented in the table, the mean score obtained by the students in pre-test was 64,85 and the standard deviation was 6,59, whereas the mean score of the students in post-test was 79,04 and standard deviations was 6,48. It revealed in the table that pre-test and post-test obtained by the students was different. It can be assumed it here that animation film assisted students a lot in writing narrative text.

The analysis showed that alternative hypothesis $\left(\mathrm{H}_{1}\right)$ was accepted, meanwhile, the null hypothesis $\left(\mathrm{H}_{0}\right)$ was rejected. It means that animation film work well in supporting students' writing of narrative text.

\section{DISCUSSION}

Referring the $\mathrm{t}$-test value, the table below showed that $\mathrm{t}$-test value (14.62) is greater that the $\mathrm{t}$ table value $(1,725)$. Based on the analysis, it can be concluded that there were significant differences between the mean score of the students' pre-test and post-test, which means that teaching writing ability by using animation films can improve the students writing ability.

\section{The Significant value of Animation Film in Learning Process}

In researching the significant value of the assistance of animation film in teaching writing of narrative text, the researcher distributed questionnaire consisting of several questions to find out how significant the use of animation films in supporting students' writing skills of narrative text.

The percentage of students' questionnaire score intervals to find out how significant the use of

In this section, the researcher explains in detail about the finding of the research. As mentioned earlier, the research was started after the researcher found some facts when making mini research as prior data investigation in one of junior high school in Parepare. The short research was focused on the teaching of English particularly on the aspect of English writing. It is revealed in the mini research that students as well as teacher still struggling in teaching learning of English writing skill. They still face some challenges in learning English such as lack of vocabularies in expression ideas in written form, lack of ideas in differentiating types of writing text, low varieties of teaching media, model and strategies. These common problems in writing teaching is also sounded by prior researchers like Ashraf and Bilal 2016; Toba, et. al, 2019; Mohammad and Hazarika, 2016; Inayah and Nanda, 2016. 
There are several facts why researchers conducted this study with the aim of improving students' writing skills. The first is based on a written test the researcher performs during observation. Researchers found that most students agreed reported that writing as a skill that is quite difficult in English. The second is the researcher found the fact that students were bored with the learning media used by the teacher in teaching. This data was collected through students' statements in the form of questionnaires distributed to students and it was found that around $60 \%$ of students expressed dissatisfaction with the learning media used in the classroom. The learning media applied by the teacher in the learning process is still conventional, such as the teacher only uses books as a medium in the learning process. Therefore, interactive learning media should accompany teacher in situating interesting learning zone, and it should be made by based on the students' need as supported by the research of Ramadhani, Gafari and Marice (2019). The English teachers should try to use interesting learning media to motivate students to be more active in the learning process as well as create fun activities, especially in the teaching of writing narrative text.

Furthermore, by considering the data taken from the prior research, this study offered one opt in assisting students in learning English writing particularly in writing narrative text namely animated film. The findings showed that there is a better value the students gain in learning English writing after treated using animation film.

In collecting the data, pre-test and post-test was the instrument applied before giving the treatment. Pre-test on the respondent's class was used to determine the students' writing skills. The pre-test was given to all students using 80 minutes (2 hours of lessons) for the respondent class. After conducting the pre-test, the researcher treated the respondent class four time, and gave post-test afterward. Furthermore, the students also filled in the questionnaire via google form to know the works of animation films in assisting students improving their writing skills on narrative text.
Before giving treatment, the students' writing ability was categorized on quite low level, as evidenced by the percentage of the total pre-test score and the mean score of the students from the pre-test obtained by the students was 64.85 and a standard deviation is 6.59 . Then after being given treatment four times to the students in the respondent class, the students' speaking ability was categorized as good, as evidenced by the percentage of the total post-test score and the average post-test score obtained by the students. The students were 79.04 and the standard deviation was 6.48. This means that the mean value and standard deviation of pre-test and post-test obtained by students in the respondent class are different, where the $t$-test value (14.62) is greater than the t-table value (1.725) for a significant level of 0.05 . Degrees of freedom $\mathrm{df}(\mathrm{N}-1)$ 20. It means that the learning achievement of students who are taught to use film animation is better than students who have never been taught to use film animation

As a consideration in this study, there are several tables that show the results of the data in the respondent class. First, table 1 shows the percentage of students' writing scores on the pre-test of the respondent's class. This shows that the frequency of student achievement and the percentage during pre-test is still poor and most of them get poor classification scores. Secondly, table 2 shows the percentage of students' writing scores on the posttest of the respondent class. This shows that the frequency of student achievement and the percentage is good because most students get good grades.

Thirdly, table 3 shows the standard deviation and standard deviation of student achievement in the pre-test and post-test. The table shows that the mean score of the students 'pre-test was 64.85 and the mean score of the students' final test was 79.04, while the standard deviation in the pre-test was 6.59 and in the post-test was 6.48 with the gain 14.19. This shows that the standard deviation variant has decreased before and after treatment. This happens because the researcher provides the maximum process for students in the learning process using animation films. 
Fourthly, table 4 shows the results of the t-test. The t-test value (14.62) was higher than the t-table value (1.725). That is, the null hypothesis $(\mathrm{Ho})$ is rejected and the alternative hypothesis (H1) is accepted. This shows that there is a significant difference between students who are taught using film animation better than students who have never been taught using film animation.

Based on the results of the students 'written text above, the researcher argues that the use of animation films in the learning process can work well in assisting students' writing skill on narrative text, especially class IX in UPTD SMP Negeri 6 Parepare. In addition to support students' writing's ability; there are other advantages in using animation films as a medium in the learning process according to Brown (2014), such as cutting some defects Intellectual in learning, helps overcome some physical obstacles to students, presents various events continuously, provides special visual experiences in order to gain deeper understanding, and allows students to make real actions or imagine an event or process.

Another advantage obtained is the power of creation as stated by Harmer (2014) who says that one of the advantages of using animation films in the learning process is the power of creation, which means that students who make their own films as a medium in the learning process will have the potential to create something memorable and fun. Assignments using animation films will make students creative and can make students more excited to learn. A different study by Gagne (2012) who detailed animated videos can increase students' motivation to write, by understanding the concept and then improving their learning outcomes. In addition, the use of animated video as a medium of information relevant to the processing model is divided into eight stages, namely the stages of motivation, recognition, acquisition, retention, calling, transfer, and response, until strengthening. Based on the explanation above, it can be concluded that animation films provide an advantage if they are used as a medium during the learning process.
Another advantage obtained is the power of creation as stated by Harmer (2014) who says that one of the advantages of using animation films in the learning process is the power of creation, which means that students who make their own films as a medium in the learning process will have the potential to create something memorable and fun. Assignments using animation films will make students creative and can make students more excited to learn. A different study by Gagne (2012) who detailed animated videos can increase students' motivation to write, by understanding the concept and then improving their learning outcomes. In addition, the use of animated video as a medium of information relevant to the processing model is divided into eight stages, namely the stages of motivation, recognition, acquisition, retention, calling, transfer, and response, until strengthening. Based on the explanation above, it can be concluded that animation films provide an advantage if they are used as a medium during the learning process.

In addition, there were some researchers have already conducted research to improve students' writing ability by using animation films, for example, a study by Siswanjaya, 2017; Dyah, 2013; Zennet, 2016; Tatum, 2011; Abdia, 2016. Here, the researcher has different sample and location of the study as well as different teaching text focus though the media used is similar; animation film. In collecting the data, writing test and questionnaire were used. It revealed in the data that before using animation films in the learning process, students felt uninterested in participating in the learning process because limited media applied by the teacher which affect students' motivation in learning. After using animation films as an alternative media in teaching writing narrative text, there is positive support emerged in students and their way of writing is better than before. The students enjoyed learning using animation film as it makes them more enthusiastic in the learning process and it features moving videos and have sound effects.

\section{CONCLUSION}


Based on the findings and discussion presented in the previous chapter, it was found that teaching writing through utilization of animation films can improve the writing of the ninth grade students of UPTD SMP Negeri 6 Parepare. It was supported by the data in pre-experimental class and in the posttest. From the data found, it showed that there was different students' mean score between before and after giving treatment. The students' score after giving treatment was higher than before giving treatment. Besides that, in applying t-test of the students' post-test for both of the classes, it was found that the $\mathrm{t}$-test was greater than $\mathrm{t}$-table value.

Apart from the data above, the use of animation films in the learning process was a new way for UPTD SMPN 6 Parepare to make students more enthusiastic about the learning process. For the ninth grade students of English especially in teaching writing, the teacher only used handbooks and power point to teach, so that it made them bored. Therefore, the researcher tried to use animation films to find out how effective the media was in improving students' writing skills and it was proven that the use of animation films could help students improve their writing skills because students thought that by using animation films the learning process was more fun because animation films were not only displaying video still provides sound effect so that the learning process was more varied.

The study forward some suggestions such the teacher should make a technique or strategies in teaching writing that can make students easy understand. Then, the next researchers may do more research on animation films from other issues.

\section{REFERENCES}

Abdia, K. R. (2016). The implementation of aimated short movie in teaching writing narrative text to the tenth graders of man sidoarjo (Doctoral dissertation, Universitas Muhammadiyah Sidoarjo)

Asrifan, A. (2015). The Use of Pictures Story in Improving Students' Ability to Write Narrative Composition", International Journal of Language and Linguistics.
Dyah. S. N. (2012). Improving Ability to Write Narrative Text Using Animation Movies of the Eleventh Grade Students at Man 2 Yogyakarta in the Academic Year of 2012/2013.

Faghihi, U., Brautigam, A., Jorgenson, K., Martin, D., Brown, A., Measures, E., \& MaldonadoBouchard, S. (2014). How gamification applies for educational purpose specially with college algebra. Procedia Computer Science, 41, 182-187.

Fareed, M., Ashraf, A., \& Bilal, M. (2016). ESL learners' writing skills: Problems, factors and suggestions. Journal of Education and Social Sciences, 4(2), 81-92.

Gagne, J. C. (2012). Learning concepts of cinenurducation: An integrative review. Nurse education today, 32(8), 914-919.

Harmer, J. (2014). Review: Methodology in Language Teaching: An Anthology of Current Practice. ELT Journal. https://doi.org/10.1093/elt/58.1.80.

Husni, R. (2019). The Effect of Outdoor Classroom Activity to the Writing Skill for Students English Department. IJECA (International Journal of Education and Curriculum Application).

Hyland, K. (2002). Authority and invisibility: Authorial identity in academic writing. Journal of Pragmatics. https://doi.org/10.1016/S03782166(02)00035-8.

Inayah, N., \& Nanda, R. P. (2016). Efforts to improve writing skills of high school students. Studies in English Language and Education, 3(1), 50-64.

Karlinasari, I. (2019). The implementation of Cognitive Strategy Instruction in Writing (CSIW) strategy in teaching writing for the eight grade students at Mts Al-Karomah Winong Ngawi. English Teaching Journal : A Journal of English Literature, Language and Education.

Mohammad, T., \& Hazarika, Z. (2016). Difficulties of learning EFL in KSA: Writing skills in context. International Journal of English Linguistics, 6(3), 105-117. 
Sarifah, N. T., \& Apsari, Y. (2020). The Use of Picture and Picture Technique in Improving Student Writing Skill. PROJECT (Professional Journal of English Education).

Seli, S. \& Amelia, Y. (2021). The Effectivenes of Role Play in Improving English Speaking Skill to the Tenth Grade Students of Ma Nida'ul Khairaat Pombewe. Datokarama English Education Journal.

Siswanjaya, S., Saukah, A., \& Ivone, F. M. (2017). Implementing Guiding Questions Combined with Animation Film to Improve Ninth Graders' Narrative Writing Skill. Jurnal Pendidikan Humaniora, 5(1), 33-39. https://doi.org/10.17977/um030v5i12017p033.

Sutrisno, A. D. (2020) . The Effect of English Conversation Videos on Students' Listening Skill". Ethical Lingua: Journal of Language Teaching and Literature.

Syawaluddin, A., Rachman, S. A., \& Khaerunnisa. (2020). Developing Snake Ladder Game Learning Media to Increase Students' Interest and Learning Outcomes on Social Studies in Elementary School, Simulation \& Gaming.
Wahyuni, S. (2017). The Use of English Animated Movie to Improve Students' Ability in Writing Descriptive Text. English Education Journal, 4(1).

Ramadhani, M., Gafari, M. O. F., \& Marice, M. (2019). Development of Interactive Learning Media on Material Writing Short Story Texts Based on Experience. Budapest International Research and Critics in Linguistics and Education (BirLE) Journal, 2(1), 91-102.

Tarigan, H. G. (2008). Menulis sebagai suatu keterampilan berbahasa. Bandung: Angkasa.

Tatum, A. (2011). The Use of Animated Film to Improve Students' Ability in Writing Narrative Text. Unpublished Thesis. English Language Education of Walisongo State Institute for Islamic Studies Semarang., 20-21.

Terry, R. M., \& Hughes, A. (2010). Testing for Language Teachers. The Modern Language Journal, $\quad 74(3), \quad 383$. https://doi.org/10.2307/327632

Toba, R., Noor, W. N., \& Sanu, L. O. (2019). The Current Issues of Indonesian EFL Students' Writing Skills: Ability, Problem, and Reason in Writing Comparison and Contrast Essay. Dinamika Ilmu, 19(1), 57-73. 